\title{
Penentuan Pusat Pertumbuhan pada Satuan Wilayah Pengembangan (SWP) Kediri Provinsi Jawa Timur
}

\author{
(Determination The Growth Poles of Region Development Unit (RDU) Kediri \\ East Java Province)
}

\author{
Danu Hadi Basito, Riniati*, Sebastiana Viphindrartin \\ Jurusan Ilmu Ekonomi Studi Pembangunan, Fakultas Ekonomi dan Bisnis, Universitas Jember (UNEJ) \\ Jln. Kalimantan 37, Jember 68121 \\ E-mail: riniati.prawiro@gmail.com
}

\begin{abstract}
Abstrak
Penelitian yang dilakukan bertujuan untuk : (1) mengidentifikasi sektor ekonomi yang berpotensi menjadi sektor basis sebagai penentu wilayah pusat pertumbuhan pada Satuan Wilayah Pengembangan Kediri Jawa Timur; (2) mengidentifikasi sektor ekonomi yang memiliki keunggulan kompetitif di Satuan Wilayah Pengembangan Kediri Jawa Timur; (3) mengklasifikasikan wilayah pada masing-masing Kabupaten/Kota di Satuan Wilayah Pengembangan Kediri Jawa Timur ; (4) mengidentifikasi wilayah berdasarkan ketersediaan fasilitas pelayanan di Satuan Wilayah Pengembangan Kediri Jawa Timur; dan (5) mengidentifikasi wilayah yang memiliki potensi kekuatan interaksi antar wilayah sebagai lokasi pusat pengembangan di Satuan Wilayah Pengembangan Kediri Jawa Timur. Jenis penelitian yang digunakan yakni bersifat deskriptif kuantitatif dengan menggunakan data sekunder yang diperoleh dari Badan Pusat Statistik masing-masing wilayah dan instansi terkait. Alat analisis yang digunakan adalah analisis location quotient, analisis shift share, analisis tipologi klassen, analisis skalogram, dan analisis model gravitasi. Hasil analisis menunjukkan bahwa Kota Kediri muncul sebagai pusat pertumbuhan pada Satuan Wilayah Pengembangan Kediri Jawa Timur dengan keunggulan wilayah dari dua segi yakni segi kemampuan basis wilayah (Location Quotient) dan segi pendapatan perkapita yang tinggi (Tipologi Klassen) dengan daerah hinterland antara lain Kab. Nganjuk, Kab. Trenggalek, serta Kab. Kediri dan Kab. Tulungagung.
\end{abstract}

Kata kunci: Gravitasi, Location Quotient, Pusat Pertumbuhan, Shift Share, Skalogram, Tipologi Klassen.

\begin{abstract}
Research conducted aims to: 1) to identify the potential economic sectors as the base sector as a determinant of the central region of growth in the Region Development Unit (RDU) Kediri East Java; 2) to identify economic sectors that have a competitive advantage in the Region Development Unit (RDU) Kediri East Java; (3) to classify the region in each Regency / City in the Region Development Unit (RDU) Kediri East Java; (4) to identify region based on the availability of service facilities in Region Development Unit (RDU) Kediri East Java; and (5) to identify region with potential interaction strength among regions as the central development areas in Region Development Unit Kediri East Java'. An analysis method that used a method of quantitative descriptive analysis by using secondary data obtained from the Statistic Indonesia and other institutions needed. The analysis is use location quotient analysis, shift share analysis, typologi klassen analysis, scalogram analysis, dan gravitation model analysi. The Analysis showed Kediri City emerges as a growth poles in Region Development Unit Kediri East Java with regional advantages from two aspects namely regional capability (Location Quotient analysis) and high per capita income (Tipology Klassen analysis) with hinterland area such as Kab. Nganjuk, Kab. Trenggalek, and Kab. Kediri and Kab. Tulungagung.
\end{abstract}

Keywords: Gravitation, Growth Poles, Location Quotient, Scalogram, Shift Share, Typologi Klassen.

\section{Pendahuluan}

Pembangunan, menurut Schumpeter, adalah perubahan spontan dan terputus-putus dalam keadaan stasioner yang senantiasa mengubah dan mengganti situasi keseimbangan perdagangan bebas dan persaingan bebas antar bangsa akan menadi ketat, maka diperlukan penguatan daya saing ekonomi masing-masing wilayah (Adisasmita, 2005: 204).

Pembangunan ekonomi merupakan suatu proses yang menyebabkan pendapatan per kapita penduduk suatu negara meningkat secara berkelanjutan dalam jangka panjang (Sukirno, 2006: 10).

Pembangunan dibagi menjadi dua macam yakni pembangunan seimbang dan pembangunan tidak seimbang. Menurut Lewis pembangunan seimbang ditekankan pada keuntungan yang akan diperoleh dari terciptanya interpendensi yang efisien antara berbagai sektor. Sedangkan menurut Hirschman pembangunan tidak seimbang merupakan pembangunan yang terpusat pada sektor tertentu dan akan lebih mempertinggi efisiensi penggunaan sumber daya yang tersedia.

Untuk mengendalikan perkembangan kawasan perkotaan yang cenderung terus membesar, dan berpotensi mendorong perkembangan mega-urban tersebut, serta menyeimbangkan perkembangan perkotaan, dan mengendalikan perkembangan kawasan terbangun di perkotaan serasi dengan kawasan pedesaan sesuai daya dukung, serta prinsip-prinsip pembangunan berkelanjutan, maka struktur ruang wilayah dalam Rencana Tata Ruang Wilayah Provinsi (RTRWP) Jawa Timur dibagi menjadi sembilan Satuan Wilayah Pengembangan (SWP). Penentuan sembilan SWP di Jawa Timur berdasarkan kecenderungan pergerakan manusia,

* Corresponding author 
barang dan jasa, serta karakteristika wilayah. Orientasi pergerakan manusia, barang dan jasa di Jawa Timur cenderung memusat pada titik-titik tertentu, dan mengarah pada wilayah yang telah terlebih dahulu berkembang (Laporan Kinerja Instansi Pemerintah Jawa Timur, 2015).

Wilayah Pengembangan (WP) Kediri dan sektitarnya merupakan salah satu dari sembilan wilayah pengembangan di Jawa Timur dengan pusat di Kota Kediri yang terdiri dari Kota Kediri, Kabupaten Nganjuk, Kabupaten Tulungagung, Kabupaten Trenggalek, dan Kabupaten Kediri dengan fungsi antara lain pertanian tanaman panga, hortikultura, perkebunan, kehutanan, peternakan, pertambangan, pendidikan, kesehatan, pariwisata, perikanan, dan industri (Peraturan Daerah Provinsi Jawa Timur, 2012)

Pemilihan wilayah pengembangan Kediri sebagai lokasi penelitian dilatarbelakangi oleh dua kabupaten kota yang memiliki kemampuan lebih dibandingkan wilayah lain yakni Kabupaten Nganjuk dengan produksi hortikultura bawang merah mencapai 136.151 Ton dan menempati produksi terbesar pertama se-Jawa Timur terbukti dengan persentase produksi yang mencapai $49,13 \%$ produksi Jawa Timur serta menjadi kontributor produksi terbesar kedua se-Indonesia terbukti dengan persentase mencapai $11,08 \%$ produksi bawang merah Indonesia. Sedangkan Kota Kediri memiliki kemampuan yang didukung dengan sektor industri pengolahan lebih tepatnya industri tembakau yang menempati kontributor terbesar pertama untuk produksi industri tembakau se-Jawa Timur dengan produksi mencapai $57.204,80$ miliar rupiah persentase sebesar $60,3 \%$ produksi Jawa Timur.

Rumusan masalah terdiri atas beberapa permasalahan terkait pada kabupaten/kota Satuan Wilayah Pengembangan Kediri, sebagai berikut (1) bagaimana potensi sektor ekonomi wilayah, (2) seberapa besar nilai keunggulan kompetitif masing-masing daerah, (3) bagaimana klasifikasi wilayah, (4) seberapa besar kekuatan sentralitas atas keberadaan sarana infrastruktur, dan (5) bagaimana kekuatan interaksi ekonomi masing-masing wilayah. Sedangkan tujuan dari penelitian, antara lain (1) mengidentifikasi sektor ekonomi yang berpotensi menjadi sektor basis sebagai penentu wilayah pusat pertumbuhan Satuan Wilayah Pengembangan Kediri Jawa Timur; (2) mengidentifikasi sektor ekonomi yang memiliki keunggulan kompetitif di Satuan Wilayah Pengembangan Kediri Jawa Timur; (3) mengklasifikasikan wilayah pada masing-masing Kabupaten/Kota di Satuan Wilayah Pengembangan Kediri Jawa Timur ; (4) mengidentifikasi wilayah berdasarkan ketersediaan fasilitas pelayanan di Satuan Wilayah Pengembangan Kediri Jawa Timur; dan (5) mengidentifikasi wilayah yang memiliki potensi kekuatan interaksi antar wilayah sebagai lokasi pusat pengembangan di Satuan Wilayah Pengembangan Kediri Jawa Timur.

\section{Metode}

\section{Jenis dan Sumber Data}

Jenis penelitian yang digunakan yakni bersifat deskriptif kuantitatif, yaitu penelitian yang bertujuan memberikan gambaran agar dapat memahami karakteristik obyek penelitian dari berbagai aspek secara numeric (kuantitatif).

Data yang digunakan dalam penelitian ini adalah data sekunder, yang diperoleh dari Badan Pusat Statistik Jawa Timur, BPS Kota Kediri, BPS Kab. Kediri, BPS Kab. Nganjuk, BPS Kab. Trenggalek, dan BPS Kab. Tulungagung, Badan Perencanaan Pembangunan Daerah maupun instansi terkait yang menyediakan data untuk penelitian ini. Beberapa data lainnya adalah jumlah fasilitas ekonomi dan sosial, jumlah penduduk, PDRB pada tiap kabupaten, pendapatan perkapita kabupaten, dan jarak antar kabupatem/kota.

\section{Metode Analisis Data \\ Analsis Location Quotient}

Location quotient (kuosien lokasi) adalah suatu perbandingan tentang besarnya peranan suatu sektor/industri di suatu daerah terhadap besarnya peranan sektor/industri tersebut secara nasional. Ada banyak variabel yang bisa diperbandingkan, tetapi yang umum adalah nilai tambah (tingkat pendapatan) dan jumlah lapangan kerja. Berikut digunakan adalah nilai tambah (tingkat pendapatan), rumusnya sebagai berikut (Tarigan, 2014: 82-83).

$\mathrm{LQ}=(\mathrm{Si} / \mathrm{S}) /(\mathrm{Ni} / \mathrm{N})$

dimana :

LQ = Besarnya kuosien lokasi suatu sektor ekonomi

$\mathrm{Si} \quad=$ PDRB sektor $i$ di Kabupaten/Kota

$\mathrm{S} \quad=$ Total PDRB di Kabupaten/Kota

$\mathrm{Ni} \quad=$ PDRB sektor $i$ secara Provinsi Jawa Timur

$\mathrm{N} \quad=$ Total PDRB di Provinsi Jawa Timur

Interpretasi hasil analisis LQ adalah sebagai berikut :

1. Apabila nilai LQ $>1$, sektor potensial/unggulan di kabupaten tersebut, artinya sektor tersebut mempunyai peran ekspor di wilayah

2. Apabila nilai $\mathrm{LQ}=1$, menunjukkan peranan sektor tersebut di kabupaten setara dengan peranan sektor tersebut di Kabupaten/Kota yang bersangkutan

3. Apabila nilai LQ $<1$, sektor tersebut tidak mempunyai peran sektor ekspor di wilayah dan justru akan mendatangkan impor dari wilayah lain.

\section{Analisis Shift Share (Differential Shift)}

Differential Shift Component $(D)$ disebut juga komponen lokasional atau regional dari sisa atau kelebihan. Komponen tersebut mengukur besarnya shift regional netto yang diakibatkan oleh sektor-sektor industri tertentu yang tumbuh lebih cepat atau lebih lambat di daerah yang bersangkutan dibandingkan tingkat nasional yang disebabkan oleh faktorfaktor lokasional intern. Jadi suatu daerah yang mempunyai keuntungan lokasional seperti sumber daya yang melimpah/efisien, akan mempunyai differential shift component yang positif, sedangkan daerah yang secara lokasional tidak menguntungkan akan mempunyai komponen yang negatif (Tarigan, 2014: 86-87).

$D_{r, i, t}=\left\{Y_{r, i, t}-\left(Y_{N, i, t} / Y_{N, i, t-n}\right) Y_{r, i, t-n}\right\}$

dimana,

$E_{r, i, t}$ : PDRB sektor/subsektor i di wilayah kabupaten/kota tahun akhir analisis

$\mathrm{E}_{\mathrm{r}, \mathrm{i}, \mathrm{t}-\mathrm{n}}$ : PDRB sektor/subsektor i di wilayah kabupaten tahun awal analisis

$\mathrm{E}_{\mathrm{N}, \mathrm{i}, \mathrm{t}} \quad$ : PDRB sektor/subsektor i di wilayah Provinsi Jawa Timur tahun akhir analisis

$\mathrm{E}_{\mathrm{N}, \mathrm{i}, \mathrm{t}-\mathrm{n}}$ : PDRB sektor/subsektor i di wilayah Provinsi Jawa 
Timur tahun awal analisis

\section{Analisis Tipologi Klassen}

Metode Tipologi Klassen digunakan untuk mengetahui pengelompokkan daerah menurut struktur pertumbuhannya. Dengan menggunakan Matrix Klassen dapat dilakukan 4 pengelompokan daerah dengan menggunakan laju pertumbuhan dan pendapatan perkapita sebagai indikator. Namum demikian perlu dicatat bahwa pengelompokkan ini adalah bersifat dinamis karena perubahan laju pertumbuhan dan pendapatan perkapita mudah terjadi pada perkembangan kegiatan pembangunan (Sjafrizal, 2008: 179).

Tabel 1. Matrix Klassen

\begin{tabular}{lll}
\hline $\begin{array}{l}\text { Pendapatan } \\
\text { Perkapita }\end{array}$ & Yi $>$ Yn & Yi $<$ Yn \\
$\begin{array}{l}\text { Pertumbuhan } \\
\text { Ekonomi }\end{array}$ & & \\
\hline & $\begin{array}{l}\text { Kuadran I } \\
\text { (Daerah maju }\end{array}$ & $\begin{array}{l}\text { Kuadran III } \\
\text { (Daerah }\end{array}$ \\
ri $>$ rn & $\begin{array}{l}\text { tambuh) cepat } \\
\text { Kuadran II } \\
\text { (Daerah maju } \\
\text { (Di cepat) } \\
\text { tapi tertekan) }\end{array}$ & $\begin{array}{l}\text { Kuadran IV } \\
\text { (Daerah relatif } \\
\text { tertinggal) }\end{array}$ \\
\hline
\end{tabular}

ri : Laju pertumbuhan PDRB kabupaten $\mathrm{i}$

rn : Laju pertumbuhan nasional

Yi : Pendapatan per kapita kabupaten i

Yn : Pendapatan per kapita nasional

\section{Analisis Skalogram}

Fungsi alat analisis indeks sentralitas digunakan bersama dengan analisis skalogram, yaitu digunakan untuk mengetahui struktur/hirarki pusat pertumbuhan ekonomi yang ada dalam suatu wilayah dengan menghitung berapa jumlah fungsi yang ada, berapa jenis fungsi serta seberapa besar frekuensi keberadaan suatu fungsi dalam satu satuan wilayah (Riyadi, 2003: 97).

\section{Analisis Model Gravitasi}

Kekuatan interaksi antara dua wilayah yang berbeda dapat diukur dengan memperhatikan jumlah penduduk dan jarak antara kedua wilayah tersebut. Model gravitasi adalah model yang sering digunakan untuk melihat kaitan potensi suatu lokasi dan besarnya wilayah pengaruh dari potensi tersebut (Nisa, 2014).

\section{Hasil dan Pembahasan}

\section{Hasil}

\section{Analisis Location Quotient}

Tabel 2. Hasil Analisis Location Quotient

\begin{tabular}{llll}
\hline No. & Daerah & Nilai LQ & Peringkat \\
\hline 1 & Kab. Nganjuk & 2,231 & II \\
2 & Kab. Tulungagung & 1,346 & V \\
3 & Kab. Trenggalek & 1,696 & III \\
4 & Kab. Kediri & 1,384 & IV \\
5 & Kota Kediri & 2,753 & I \\
\hline
\end{tabular}

Sumber: Hasil olahan

Berdasarkan Tabel 2 diperoleh Kota Kediri memiliki nilai basis tertinggi karena industri tembakau yang dimiliki oleh Kota Kediri menguasai pangsa pasar dan berkontribusi besar pada produksi industri tembakau di Jawa Timur dengan persentase kontribusi sebesar $78-80 \%$ dari produksi Jawa Timur. Sedangkan untuk Kab. Tulungagung memiliki nilai basis wilayah terendah karena kontribusi dari produksi wilayah lebih kecil dibanding dengan kabupaten/kota pada Satuan Wilayah Pengembangan Kediri Jawa Timur yang terbukti bahwa pada sektor basis tertinggi di Kab. Tulungagung di topang oleh sektor jasa kesehatan dan hanya berkontribusi sebesar 2,8-3,0\% produksi Jawa Timur, meskipun secara PDRB memiliki nilai lebih besar dari sektor jasa kesehatan seperti sektor pertanian, kehutanan, dan perikanan, sektor industri pengolahan, dan sektor perdagangan besar dan eceran; reparasi mobil akan tetapi hal tingginya nilai PDRB tersebut belum tentu unggul pada kontribusi produksi di Jawa Timur yang terbukti dengan sektor pertanian, kehutanan, dan perikanan persentase kontribusi berkisar 2,7-2,8\% dibanding produksi Jawa Timur, sektor industri pengolahan dengan persentase kontribusi sebesar 1,16-1,20\% dibanding produksi Jawa Timur, dan sektor perdagangan besar dan eceran: reparasi mobil dengan persentase kontribusi produksi sebesar 1,93-1,98\% dibanding produksi Jawa Timur.

\section{Analsis Shift Share}

Tabel 3. Hasil Analisis Shift Share (differential shift)

\begin{tabular}{llll}
\hline No. & Kabupaten / Kota & $\begin{array}{l}\text { Differential } \\
\text { Shift }\end{array}$ & Persentase \\
\hline 1 & Kab. Nganjuk & $-5,195$ & $-0,18$ \\
2 & Kab. Trenggalek & 70,139 & 3,40 \\
3 & Kab. Tulungagung & $-48,328$ & $-1,08$ \\
4 & Kab. Kediri & $-163,350$ & $-3,51$ \\
5 & Kota Kediri & $-4201,318$ & $-32,50$ \\
\hline
\end{tabular}

Sumber: Hasil olahan

Berdasarkan Tabel 3 diperoleh Kab. Trenggalek memiliki potensi dengan nilai differential shift tertinggi sebesar 70,139 sedangkan Kota Kediri sebagai daerah dengan differential shift terendah yakni sebesar -4.201,318. Kab. Trenggalek memiliki daya saing dari segi kuntungan lokasional, yang ditandai dengan nilai differential shift yang positif dibanding kabupaten/kota lainnya. Pertumbuhan ekonomi yang terjadi di Kab. Trenggalek didukung oleh adanya keunggulan kompetitif yang menyumbang sebesar 3,4\% terhadap pertambahan nilai PDRB tahun 2011-2015, sedangkan kabupaten/kota lainnya mengalami kemerosotan keunggulan lokasional yang ditandai dengan nilai differential shift yang negatif. Wilayah yang memiliki nilai differential shift terendah terjadi di Kota Kediri dengan nilai sebesar $-4.201,318$ dengan persentase $-32,50 \%$ dari pertambahan nilai PDRB Kota Kediri tahun 2011-2015. Namun demikian, kemerosotan keuntungan lokasioal tersebut dapat tertutupi dengan nilai national share serta proportional shift yang membantu adanya pertumbuhan ekonomi wilayah yang bersangkutan. Tingginya keuntungan lokasional yang dimiliki oleh Kab.Trenggalek yakni sesuai yang tertera pada Peraturan Daerah Provinsi Jawa Timur Nomor 5 Tahun 2012 Tentang Rencana Tata Ruang Wilayah Provinsi Tahun 20112031, dimana wilayah pengembangan Kediri memiliki fungsi wilayah yang salah satunya sebagai pengembangan kegiatan perikanan, sehingga dengan hasil analisis differential shift 
(shift share) terbukti pemerintah dapat mewujudkan fungsi tersebut pada Satuan Wilayah Pengembangan Kediri tepatnya pada Kabupaten Trenggalek. Sedangkan rendahnya nilai keuntungan kompetitif pada Kota Kediri yakni sebagai bukti bahwa pemerintah mewujudkan fungsi wilayah sebagai pengembangan kegiatan industri bukan berdasar pada keunggulan kompetitif wilayah akan tetapi berdasarkan tingginya produksi industri dari sisi basis ekonomi wilayah.

Analisis Tipologi Klassen

Tabel 4. Hasil Analisis Tipologi Klassen

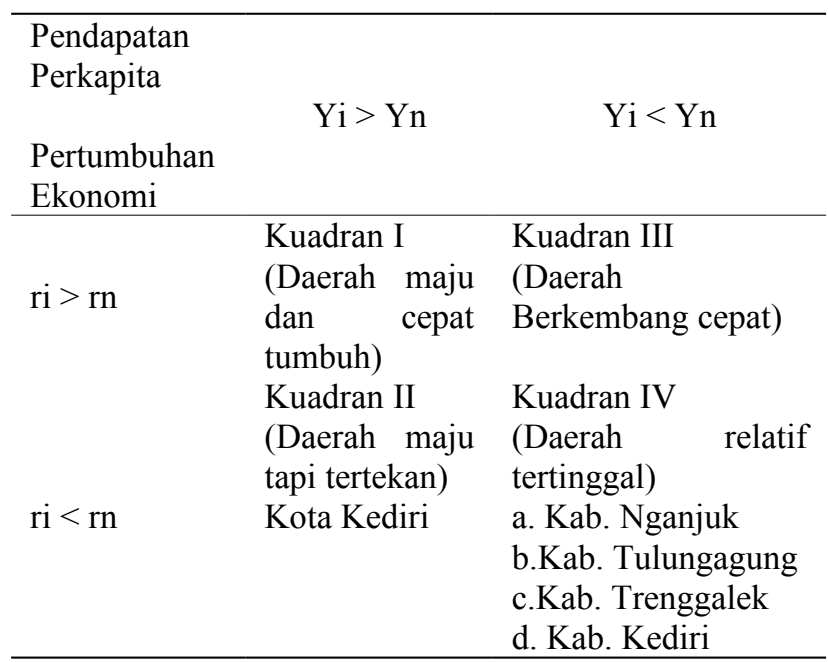

Sumber: Hasil olahan

Berdasarkan Tabel 4 diperoleh hasil klasifikasi wilayah Kabupaten/Kota di Satuan Wilayah Pengembangan Kediri Jawa Timur pada Tahun 2015 sebagai berikut :

a. Kuadran I merupakan kabupaten/kota yang memiliki kriteria laju pertumbuhan PDRB diatas pertumbuhan PDRB provinsi dan pendapatan perkapita diatas pendapatan perkapita provinsi. Tidak ada kabupaten/kota yang termasuk pada daerah cepat maju dan cepat tumbuh.

b. Kuadran II merupakan kabupaten/kota yang memiliki kriteria laju pertumbuhan PDRB lebih rendah dari laju pertumbuhan PDRB provinsi dan pendapatan perkapita diatas pendapatan perkapita provinsi. Kota Kediri masuk dalam klasifikasi wilayah daerah maju tapi tertekan yang terbukti dengan pendapatan perkapita daerah lebih besar dibanding dengan pendapatan perkapita provinsi (Yi $=260,516>\mathrm{Yn}=$ 34,273) dan pertumbuhan ekonomi lebih rendah dari pada pertumbuhan ekonomi provinsi $(\mathrm{ri}=5,36<\mathrm{rn}=5,44)$.

c. Kudran III merupakan kabupaten/kota yang memiliki kriteria laju pertumbuhan PDRB diatas laju pertumbuhan PDRB provinsi dan pendapatan perkapita lebih rendah dari pendapatan perkapita provinsi. Tidak ada kabupaten/kota yang termasuk sebagai daerah berkembang cepat.

d. Kuadran IV merupakan kabupaten/ kota yang memiliki kriteria laju pertumbuhan PDRB lebih rendah dari laju pertumbuhan provinsi dan pendapatan perkapita lebih rendah dari pendapatan perkapita provinsi. Terdapat empat kabupaten yang masuk klasifikasi ini yaitu : Kab. Nganjuk, Kab. Tulungagung, Kab. Trenggalek, dan Kab. Kediri yang terbukti dengan pertumbuhan ekonomi daerah lebih rendah dari pada pertumbuhan ekonomi provinsi (ri $=5,04$; 4,99; $5,03 ; 4,88 ;<\mathrm{rn}=5,44)$ dan nilai pendapatan perkapita daerah lebih rendah dari pada pendapatan perkapita provinsi ( $\mathrm{Yi}=14,280 ; 21,863 ; 15,236 ; 15,517<\mathrm{Yn}=34,273)$.

\section{Analisis Skalogram dan Indeks Sentralitas}

Tabel 5. Hasil Analisis Skalogram dan Indeks Sentralitas

\begin{tabular}{|c|c|c|c|}
\hline No. & Kabupaten/Kota & $\begin{array}{l}\text { Indeks } \\
\text { Sentralitas }\end{array}$ & $\begin{array}{l}\text { Hirarki } \\
\text { Wilayah }\end{array}$ \\
\hline 1 & Kab. Nganjuk & 318.645 & $\mathrm{I}$ \\
\hline 2 & $\begin{array}{l}\text { Kab. } \\
\text { Tulungagung }\end{array}$ & 56.937 & IV \\
\hline 3 & Kab. Trenggalek & 106.500 & III \\
\hline 4 & Kab. Kediri & 195.627 & II \\
\hline 5 & Kota Kediri & 37.815 & $\mathrm{~V}$ \\
\hline
\end{tabular}

Sumber: Hasil olahan

Berdasarkan Tabel 5 diperoleh hasil analisis skalogram dan indeks sentralitas dengan Kab. Nganjuk menempati hirarki I dengan nilai sebesar 318.645 sedangkan hirarki terendah dimiliki oleh Kota Kediri dengan nilai sebesar 37.815. Tingginya indeks sentralitas di Kabupaten Nganjuk ditentukan oleh jumlah unit fasilitas serta jumlah keragaman fasilitas yang tersedia. Kurangnya ragam dari fasilitas suatu wilayah akan memberikan nilai lebih pada pada wilayah lain selain terbukti dengan analisis ini yang memberikan nilai lebih pada daerah yang memiliki fasilitas pelayanan yang lebih beragam juga hal tersebut akan memberikan kurangnya kenyamanan atas kebutuhan fasilitas pelayanan yang dibutuhkan oleh masyarakat.Tingginya indeks sentralitas di Kabupaten Nganjuk ditentukan oleh jumlah unit fasilitas serta jumlah keragaman fasilitas yang tersedia. Kurangnya ragam dari fasilitas suatu wilayah akan memberikan nilai lebih pada pada wilayah lain selain terbukti dengan analisis ini yang memberikan nilai lebih pada daerah yang memiliki fasilitas pelayanan yang lebih beragam juga hal tersebut akan memberikan kurangnya kenyamanan atas kebutuhan fasilitas pelayanan yang dibutuhkan oleh masyarakat.

\section{Analisis Model Gravitasi}

Tabel 6. Hasil Analisis Model Gravitasi

\begin{tabular}{lll}
\hline No & Kota / Kabupaten & Total Nilai Interaksi \\
\hline 1 & Kab. Nganjuk & $2.013 .287 .703,54$ \\
2 & Kab. Tulungagung & $1.203 .729 .026,50$ \\
3 & Kab. Trenggalek & $1.411 .583 .033,57$ \\
4 & Kab. Kediri & $25.851 .825 .728,91$ \\
5 & Kota Kediri & $23.932 .723 .541,06$ \\
\hline
\end{tabular}

Sumber: Hasil olahan

Berdasarkan Tabel 6 bahwa Kab. Kediri merupakan daerah yang memiliki kekuatan interaksi tertinggi dengan nilai sebesar . Tingginya nilai kekuatan interaksi Kabupaten Kediri dipengaruhi oleh rendahnya jarak antar wilayah yang semakin memperbesar kekuatan interaksi antar wilayah sehingga biaya dan waktu dibutuhkan juga akan semakin rendah, selain itu kekuatan interaksi juga dipengaruhi oleh populasi antar wilayah karena dengan tingginya populasi antar wilayah yang dimiliki antar wilayah maka akan memiliki kekuatan interaksi yang tinggi karena dengan tingginya populasi akan meningkatkan pula mobilitas penduduk.

\section{Pembahasan}

Berdasarkan hasil analisis location quotient, Satuan Wilayah Pengembangan Kediri Jawa Timur memiliki kemampuan basis atau kemampuan ekspor yang berbeda-beda serta 
memiliki sektor basis yang juga berbeda antar daerah terbukti dengan Kab. Nganjuk memiliki kemampuan basis sebesar 2,231 dengan potensi basis pada sektor pertanian, kehutanan, dan perikanan, sektor pengadaan air, pengelolaan sampah, sektor real estate, sektor administrasi pemerintah, pertahanan, dan jaminan sosial wajib, sektor jasa pendidikan, dan sektor jasa lainnya. Kab. Tulungagung memiliki kemampuan basis sebesar 1,346 dengan potensi basis pada sektor pertanian, kehutanan, dan perikanan, sektor perdagangan besar dan eceran (reparasi mobil), sektor infoemasi dan komunikasi, sektor real estate, sektor administrasi pemerintah, pertahanan, dan jaminan sosial wajib, sektor jasa pendidikan, sektor kesehatan dan kegiatan sosial, dan sektor jasa lainnya. Kab. Trenggalek memiliki kemampuan basis sebesar 1,696 dengan potensi basis pada sektor pertanian, kehutanan, dan perikanan, sektor pertambangan dan penggalian, sektor informasi dan komunikasi, sektor jasa keuangan dan asuransi, sektor real estate, sektor administrasi pemerintah, pertahanan, dan jaminan sosial wajib, sektor jasa pendidikan, sektor kesehatan dan kegiatan sosial, dan jasa lainnya. Kab. Kediri merupakan daerah yang memiliki kemampuan basis sebesar 1,384 dengan potensi basis pada sektor antara lain sektor pertanian, kehutanan, dan perikanan, sektor konstruksi, sektor perdagangan besar dan eceran ; reparasi mobil, sektor informasi dan komunikasi, jasa real estate, sektor administrasi pemerintah, pertahanan dan jaminan sosial wajib, sektor jasa pendidikan, sektor jasa kesehatan dan kegiatan sosial, dan sektor jasa lainnya. Kota Kediri merupakan wilayah dengan kemampuan basis sebesar 2,753 dengan potensi basis pada sektor industri pengolahan. Dengan demikian Kota Kediri menjadi Kota yang memiliki kemampuan basis tertinggi dibanding kabupaten lain terbukti dengan nilai LQ sebesar 2,753. Nilai location quotient pada suatu wilyah dipengaruhi oleh pangsa pasar yang dimiliki daerah bersangkutan dibandingkan dengan wilayah yang lebih luas, jadi tingginya nilai LQ yang dimiliki oleh Kota Kediri terlebih dengan besarnya produksi industri tembakau di Kota Kediri menempatkan Kota Kediri memiliki pangsa pasar dan kontribusi produksi yang besar dibandingkan kabupaten kota di Jawa Timur terbukti dengan industri tembakau Kota Kediri memiliki kontribusi produksi sebesar $60-63 \%$ produksi industri tembakau di Jawa Timur.

Berdasarkan analisis shift share (differential shift) menunjukkan kemampuan kabupaten kota pada Satuan Wilayah Pengembangan Kediri Jawa Timur tentulah berbedabeda dari segi keuntungan lokaisonal mengingat perbedaan potensi yang dimiliki oleh setiap daerah terbukti dengan Kab. Nganjuk memiliki nilai keunggulan kompetitif sebesar $-5,195$ miliar rupiah atau $-0,18 \%$ dari selisih pertambahan nilai PDRB Kab. Nganjuk tahun 2011 - 2015, Kab. Tulungagung memiliki nilai keunggulan kompetitif wilayah sebesar -48,328 miliar rupiah atau $-1,08 \%$ dari selisih pertambahan nilai PDRB Kab. Tulungagung tahun 2011 2015, Kab. Trenggalek dengan nilai keunggulan kompetitif sebesar 70,139 miliar rupiah atau 3,40\% dari selisih pertambahan nilai PDRB Kab. Trenggalek tahun 2011 2015, Kab. Kediri dengan nilai keunggulan kompetitif sebesar -210,485 miliar rupiah atau $-5,49 \%$ dari selisih pertamabahan nilai PDRB Kab. Kediri tahun 2011 - 2015, dan Kota Kediri dengan keunggulan kompetitif sebesar $-4.201,318$ miliar rupiah atau $-32,50 \%$ dari selisih pertambahan nilai PDRB Kota Kediri tahun 2011 - 2015.
Dengan demikian Kab. Trenggalek menjadi daerah dengan keunggulan kompetitif wilayah tertinggi dibanding kabupaten kota pada Satuan Wilayah Pengembangan Kediri terbukti dengan nilai differential shift sebesar 70,139. Tingginya keunggulan kompetitif yang menunjukkan keunggulan Kabupaten Trenggalek dibanding kabupaten lain sesuai dengan fungsi wilayah yang tertera pada Peraturan Daerah Provinsi Jawa Timur Nomor 2 Tahun 2016 tentang Rencana Tata Ruang Wilayah Provinsi Jawa Timur, dimana Satuan Wilayah Pengembangan Kediri dengan Kabupaten Trenggalek sebagai salah satunya daerah yang termasuk dalam SWP Kediri, yakni memiliki fungsi wilayah yang salah satunya sebagai pengembangan kegiatan perikanan terbukti dengan tingginya keunggulan kompetitif Kabupaten Trenggalek sebagaian besar dikontribusi oleh sektor pertanian, kehutanan, dan perikanan lebih tepatnya subsektor perikanan dengan kontribusi pada keunggulan kompetitif sebesar 43,342 miliar rupiah dan persentase sebesar $61,79 \%$ dari nilai kompetitif kompetitif Kabupaten Trenggalek tahun 2011-2015.

Berdasarkan hasil analisis tipologi klassen menunjukkan bahwa Kab. Nganjuk, Kab. Tulungagung, Kab. Trenggalek, dan Kab. Kediri tergolong pada klasifikasi Kuadran IV yakni daerah relatif tertinggal yang terbukti dengan nilai pendapatan perkapita daerah lebih rendah dari pada pendapatan perkapita provinsi ( $\mathrm{Yi}=14,280 ; 21,863 ; 15,236$; $15,517<\mathrm{Yn}=34,273)$ dan pertumbuhan ekonomi daerah lebih rendah dari pada pertumbuhan ekonomi provinsi (ri = $5,04 ; 4,99 ; 5,03 ; 4,88 ;<\mathrm{rn}=5,44)$. Sedangkan untuk Kota Kediri tergolong pada klasifikasi Kuadran I yakni daerah maju tapi tertekan yang terbukti dengan pendapatan perkapita daerah lebih besar dibanding dengan pendapatan perkapita provinsi $(\mathrm{Yi}=260,516>\mathrm{Yn}=34,273)$ dan pertumbuhan ekonomi lebih rendah dari pada pertumbuhan ekonomi provinsi ( $\mathrm{ri}=5,36<\mathrm{rn}=5,44)$. Diperoleh bahwa Kota Kediri tergolong pada klasifikasi daerah tertinggi dibandingkan dengan kabupaten/kota lainnya pada Satuan Wilayah Pengembangan Kediri Jawa Timur. Tingginya pendapatan per kapita Kota Kediri dipengaruhi oleh sektor industri tembakau yang memiliki daya produksi hingga $78-79 \%$ dari total produksi Kota Kediri yakni sebesar 76.000-94.000 miliar rupiah dan kontribusi mencapai $60-63 \%$ produksi tembakau Jawa Timur. Selain itu juga didukung oleh rendahnya populasi penduduk Kota Kediri dibanding dengan kabupaten lain yakni sebesar 280.004 jiwa.

Berdasarkan analisis skalogram diperoleh hirarki-hirarki daerah pada kabupaten/kota Satuan Wilayah Pengembangan Kediri Jawa Timur. Dari segi ketersediaan infrastruktur fasilitas pelayanan suatu wilayah, hirarki I diperoleh Kab. Nganjuk dengan nilai indeks sentralitas sebesar 318.645. Hirarki II diperoleh Kab. Kediri dengan nilai indeks sentralitas 195.627. Hirarki III diperoleh Kab. Trengggalek dengan nilai indeks sentralitas sebesar 106.500. Hirarki IV diperoleh Kab. Tulungagung dengan nilai indeks sentralitas sebesar 56.937. Hirarki V diperoleh Kota Kediri dengan nilai indeks sentralitas terendah sebesar 37.815. Jadi, dari segi ketersediaan infrastruktur fasilitas pelayanan suatu wilayah, Kab. Nganjuk lebih unggul dibandingkan wilayah lain dan berpotensi sebagai pusat pertumbuhan pada Satuan Wilayah Pengembangan Kediri Jawa Timur. Tingginya indeks sentralitas di Kabupaten Nganjuk ditentukan oleh jumlah unit fasilitas serta jumlah keragaman fasilitas yang tersedia. 
Kurangnya ragam dari fasilitas suatu wilayah akan memberikan nilai lebih pada pada wilayah lain selain terbukti dengan analisis ini yang memberikan nilai lebih pada daerah yang memiliki fasilitas pelayanan yang lebih beragam juga hal tersebut akan memberikan kurangnya kenyamanan atas kebutuhan fasilitas pelayanan yang dibutuhkan oleh masyarakat.

Berdasarkan analisis model gravitasi yang telah dilakukan, diperoleh hasil bahwa Kab. Kediri merupakan wilayah dengan peringkat I dari segi interaksi antar wilayah dengan total nilai interaksi sebesar 25.851.825.728,91. Peringkat II dengan total nilai interaksi terbesar diperoleh Kota Kediri dengan nilai sebesar 23.932.723.541,06. Peringkat III diperoleh Kab. Nganjuk dengan total nilai interaksi sebesar 2.013.287.703,54. Peringkat IV diperoleh Kab. Trenggalek dengan total nilai interaksi sebesar 1.411.583.033,57. Dan peringkat $\mathrm{V}$ diperoleh $\mathrm{Kab}$. Tulungagung dengan total nilai interaksi sebesar 1.203.729.026,50. Dengan demikian dari segi interaksi antar wilayah, Kab. Kediri memiliki keunggulan dan potensi sebagai pusat pertumbuhan ekonomi. Tingginya nilai kekuatan interaksi Kabupaten Kediri dipengaruhi oleh rendahnya jarak antar wilayah yang semakin memperbesar kekuatan interaksi antar wilayah sehingga biaya dan waktu dibutuhkan juga akan semakin rendah, selain itu kekuatan interaksi juga dipengaruhi oleh populasi antar wilayah karena dengan tingginya populasi antar wilayah yang dimiliki antar wilayah maka akan memiliki kekuatan interaksi yang tinggi karena dengan tingginya populasi akan meningkatkan mobilitas penduduk baik karena kegiatan ekonomi ataupun kegiatan kegiatan lainnya, karena semakin tinggi populasi penduduk suatu wilayah maka semakin tinggi pula tenaga kerja yang meningkatkan penawaran tenaga kerja, hal tersebut akan berdampak pada tertariknya para pengusaha untuk mendirikan perusahaan karena rendahnya upah akibat dari tinggi penawaran tenaga kerja. Jadi banyaknya perusahaan yang berdiri pada wilayah tersebut akan terjadi banyak kegiatan ekonomi sekaligus meningkatkan mobilitas antar wilayah.

Tabel 7. Peringkat Daerah Berdasarkan Alat Analisis

\begin{tabular}{llllll}
\hline Analisis & $\begin{array}{l}\text { Locat } \\
\text { ionn } \\
\text { Quilayah } \\
\text { ent }\end{array}$ & $\begin{array}{l}\text { Shift } \\
\text { Share } \\
\text { (Differ } \\
\text { ential } \\
\text { Shift) }\end{array}$ & $\begin{array}{l}\text { Tipol } \\
\text { ogi } \\
\text { en }\end{array}$ & $\begin{array}{l}\text { Skalo } \\
\text { gram }\end{array}$ & $\begin{array}{l}\text { Mod } \\
\text { el } \\
\text { Grav } \\
\text { itasi }\end{array}$ \\
\hline Kab. Nganjuk & II & II & IV & $\begin{array}{l}\text { I } \\
\text { (unggu }\end{array}$ & III \\
Kab. & V & III & IV & $\begin{array}{l}\text { IV } \\
\text { IV }\end{array}$ & V \\
$\begin{array}{l}\text { Tulungagung } \\
\text { Kab. }\end{array}$ & III & I & IV & III & IV \\
$\begin{array}{l}\text { Trenggalek } \\
\text { Kab. Kediri }\end{array}$ & IV & IV & IV & II & $\begin{array}{l}\text { I } \\
\text { (ungg }\end{array}$ \\
& & & & & ul) \\
Kota Kediri & I & V & II & V & II \\
& (ungg & & (ungg & & \\
\hline
\end{tabular}

Sumber: Hasil olahan.

Berdasarkan Tabel 7 maka penentuan pusat pertumbuhan kabupaten/kota pada Satuan Wilayah Pengembangan Kediri
Jawa Timur diperoleh Kota Kediri sebagai pusat pertumbuhan ekonomi. Hal tersebut dikarenakan Kota Kediri memiliki dua keunggulan, yakni baik dari segi kemampuan basis wilayah yang dianalisis menggunakan location quotient ataupun klasifikasi wilayah yang lebih tinggi dibandingkan wilayah kabupaten/kota lain pada Satuan Wilayah Pengembangan Kediri sedangkan sebagai daerah hinterland yakni Kab. Nganjuk, Kab. Tulungagung, Kab. Trenggalek, dan Kab. Kediri. Kab. Trenggalek sebagai daerah hinterland memiliki satu keunggulan yakni dari segi keuntungan lokasional dibanding dengan kabupaten/kota lainnya yang dianalisis menggunakan differential shift (shift share). Kab. Kediri sebagai daerah hinterland memiliki satu keunggulan dari segi kekuatan interaksi antar wilayah yang memiliki kemampuan dalam hal pemerataan. Kab. Nganjuk sebagai daerah hinterland memiliki satu keunggulan dari segi keberadaan fasilitas pelayanan dengan nilai indeks sentralitas tertinggi. Dan Kab. Tulungagung merupakan daerah hinterland yang tidak memiliki keunggulan baik dari segi kemampuan basis wilayah, keuntungan lokasional, pertumbuhan ekonomi maupun pendapatan perkapita, ketersediaan fasilitas pelayanan, dan kekuatan interaksi antar wilayah.

Dengan demikian berdasarkan lima alat analisis yang digunakan diperoleh peringkat atau hirarki masing-masing wilayah yang dapat dilihat pada Tabel 7 guna dilakukan penentuan kabupaten kota sebagai pusat pertumbuhan pada Satuan Wilayah Pengembangan Kediri Jawa Timur di selanjutnya dapat digambarkan maping daerah pusat pertumbuhan dan daerah hinterland pada Satuan Wilayah Pengembangan Kediri yang dapat dilihat pada Gambar 1.

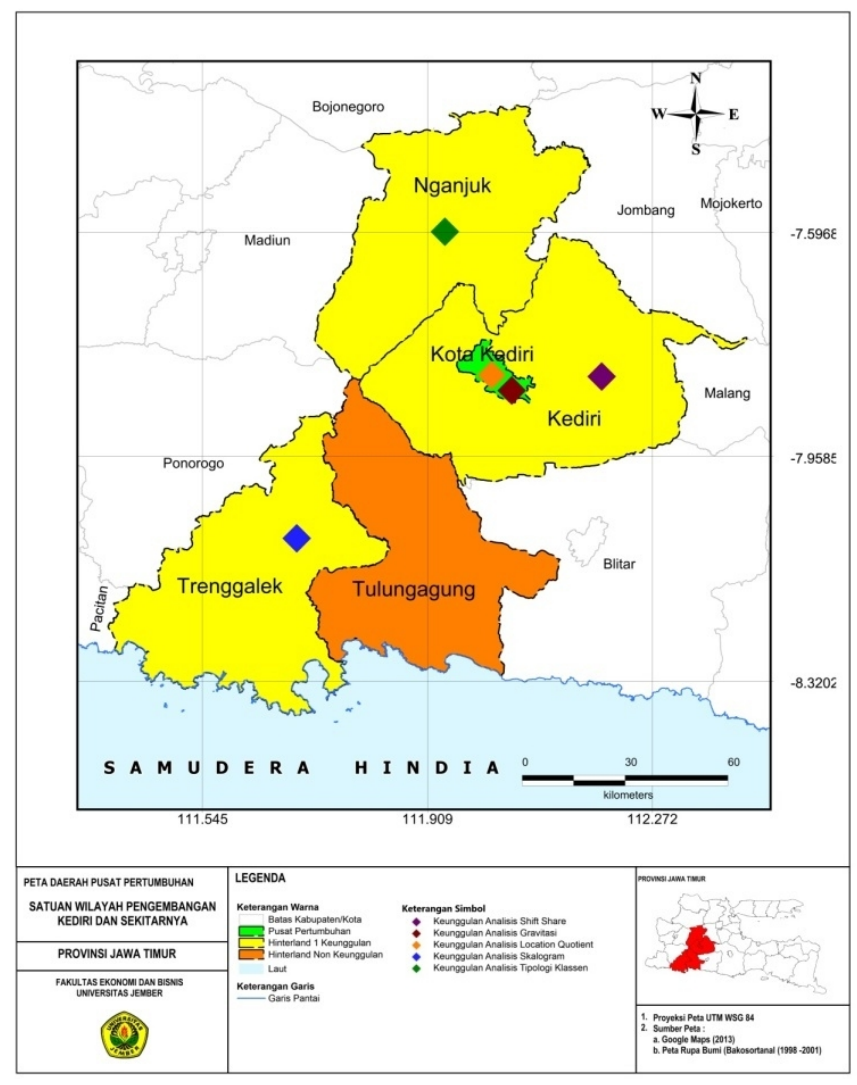

Gambar 1. Maping Daerah Pusat Pertumbuhan dan Daerah Hinterland Satuan Wilayah Pengembangan Kediri Jawa Timur. 


\section{Simpulan}

Berdasarkan hasil analisis yang dilakukan maka dapat diambil kesimpulan sebagai berikut :

1. Hasil dari analisis location quotient menunjukkan Kota Kediri merupakan daerah unggulan dengan kemampuan basis tertinggi dengan nilai basis sebesar 2,753.

2. Hasil analisis shift share (differential shift) menunjukkan Kabupaten Trenggalek merupakan daerah unggulan dengan keunggulan kompetitif wilayah tertinggi dengan nilai sebesar 70,139 miliar rupiah.

3. Hasil dari analisis tipologi klassen menunjukkan Kota Kediri menempati kuadran tertinggi daripada kabupaten kota lainnya yakni menempati kuadran II dengan klasifikasi daerah maju tapi tertekan yang terbukti dengan pendapatan perkapita wilayah lebih besar dari provinsi dan pertumbuhan ekonomi wilayah lebih rendah dibanding provinsi.

4. Perhitungan analisis skalogram menunjukkan Kabupaten Nganjuk merupakan daerah unggulan dengan nilai indeks sentralitas keberadaan sarana infrastruktur tertinggi dengan nilai sebesar 318.645.

5. Hasil analisis model gravitasi menunjukkan Kabupaten Kediri merupakan daerah unggulan dengan kekuatan interaksi antar wilayah tertinggi dengan nilai sebesar 25.851.825.728,91.

Berdasarkan dari lima kabupaten/kota pada Satuan Wilayah Pengembangan Kediri Jawa Timur dengan keunggulan masing-masing wilayah maka ditentukan satu kabupaten/kota sebagai pusat pertumbuhan ekonomi pada Satuan Wilayah
Pengembangan Kediri Jawa Timur. Berdasarkan kelima alat analisis yang digunakan, pusat pertumbuhan ekonomi Satuan Wilayah Pengembangan Kediri Jawa Timur adalah Kota Kediri yang didukung dan unggul dari dua keunggulan yakni segi kemampuan basis (Location Quotient) dan klasifikasi wilayah tertinggi dibanding kabupaten/kota pada Satuan Wilayah Pengembangan Kediri Jawa Timur (Tipologi Klassen).

\section{Referensi}

Adisasmita, H. R. 2005. Dasar-Dasar Ekonomi Wilayah. Edisi Pertama. Makassar: Graha Ilmu.

Gulo,W. 2000. Metodologi Penelitian. Jakarta: Grasindo.

Nisa, H. 2014. Analisis Potensi dan Pengembangan Wilayah Kabupaten Lebak Provinsi Banten. Skripsi. Semarang : Fakultas Ekonomi dan Bisnis Universitas Diponegoro.

Pejabat Pengelola Informasi dan Dokumentasi. 2015. Laporan Kinerja Instansi Pemerintah Provinsi Jawa Timur Tahun 2015. Jawa Timur: PPID.

Pemerintah Provinsi Jawa Timur. 2012. Peraturan Daerah Provinsi Jawa Timur Nomor 05 Tahun 2012. Diunduh dari http://jdih.surabaya.go.id/pdfdoc/perprop_20.pdf. pada tanggal 26 Januari 2017.

Pemerintah Provinsi Jawa Timur. 2015. Laporan Kinerja Instansi Pemerintah Provinsi Jawa Timur Tahun 2015. Surabaya: Pemerintah Jawa Timur.

Riyadi dan D. S. Bratakusumah. 2003. Perencanaan Pembangunan Daerah: Strategi Menggali Potensi dalam Mewujudkan Otonomi Daerah. Jakarta: Gramedia Pustaka Utama.

Sjafrizal. 2008. Ekonomi Regional : Teori dan Aplikasi. Padang: Baduose Media.

Sukirno, S. 2006. Ekonomi Pembangunan : Proses, Masalah, dan Dasar Kebijakan. Jakarta: Prenadamedia Group.. 